811.163.41'374:398 Први косовски бој 811.163.41(038) Караџић Стефановић, Вук https://doi.org/10.18485/msc.2020.49.2.ch14

Снежана Д. САМАРЏИЈА*

Оригинални научни рад

Филолошки факултет

Примљен: 27. 11. 2019.

Универзитет у Београду

Прихваћен: 12. 02. 2020.

\title{
РАСЛА ЈЕЛА НА КОСОВУ РАВНУ. КОСОВСКИ БОЈ У ВУКОВОМ РЈЕЧНИКУ ${ }^{* *}$
}

\begin{abstract}
Из Вуковог Рјечника су издвојена тумачења везана за Први косовски бој. Поред имена јунака, локалитета, појмова из сфере материјалне и духовне културе указује се на: опште формуле; стихове из косовског круга који су измењени/доследно наведени (у односу на збирке); одломке којих нема међу Вуковим записима. Подређени значењу лексике, ти примери сведоче и о процесима трајања епске песме, о Вуковом стилу, репертоару и односу према фолклорном ,,тексту”. Нарочито се истиче значај косовске тематике за српски национални идентитет.
\end{abstract}

Кључне речи: Вуков Српски рјечник, Први косовски бој, формула, усмена епика.

Пресудан за Вукову културну мисију Рјечник народнога сербског језика није ни замишљен као низ ,сувопарни речи” (Караџић 1966: 33, 11). То је била својеврсна „енциклопедија народног живота” (Деретић 1983: 255), обичаја и стваралаштва. ${ }^{1}$ Обухватајући духовну и материјалну културу, патријархални кодекс, животне реалије, реминисценције на српску историју, Вук је у Pjeчник укључио више детаља везаних за Први косовски бој² и они се распознају

*markosoft91@gmail.com

** Рад је део пројекта Српско усмено стваралаштво у интеркултурном коду (Институт за књижевност и уметност у Београду), који финансира Министарство РС.

${ }^{1}$ Вук је наводио кратке говорне форме (пословице, изразе, изреке, магијске формуле, загонетке, благослове, клетве, заклетве, здравице, поздраве, брзалице); стихове и одломке из народних „женских" и ,јуначких" песама; народне приповетке (махом шаљиве приче, анегдоте, алузије или сведени сиже), док су предања мање-више развијена. Често наглашава како је реч „из приповјетке” или се чује ,у пјесмама”. Указује на (жанровске) особености загонетке и шири (обредни) контекст импровизације здравица и басми. За истраживања српског фолклора и народне културе драгоцени су Вукови описи игара, ношње, живота села, обичаја о празницима итд. Разним аспектима Вуковог Рјечника посвећена је богата литература.

2 Део тумачења (уз: безумље, Кучевкиње, Кучево, препочети, Сибињанин Јанко, сибињски) представља и традицију о Другом косовском боју. Заступљеност примера се подудара са односом варијаната о бојевима из 1389. и 1448. у склопу Вукове збирке. Због (прописаног) обима рада овом приликом су из анализа искључена и предања о местима, задужбинама и јунацима (уз: бупило*, Двориште, затроношити, Мачва, међер, Милошева ирква намастир*, обил, скакали- 
боље од других тема српске епике. Уз појмове су примери из Вукових збирки и одломци варијаната којих нема међу његовим записима. Све те честице, расуте и азбучно поређане, имају довољно снаге да „призову” поједине песме у тематску целину. Самим тим, уочавају се механизми усмене импровизације - памћење, рецепција и преношење „текста”, колико год да (ре)конструкцију технике спевавања условљава познавање традиције.

Као део знања одређеног колектива, Вук је три пута споменуо локалитет: у полустиху „на бој на Косово” и тумачењу Видовдана. ${ }^{3}$ На догађај се алудира поређењем: „Покољ као на Косову” и исказима: „Био рват' на Косову”; „Да је мени ћело добро бити, не би Лазо на Косову погинуо”. ${ }^{4}$

\section{Честице тематског круга}

Речи, стихови и одломци - попут јачих или слабијих (поетских) сигнала, образују мотивску мрежу обликовану око догађаја. Процеси су природна последица Вукових примера из биране грађе, коју је штампао за живота. ${ }^{5}$ Те, најпознатије песме о Косову успостављају кохерентан тематски круг захваљујући Вуковом груписању записа у збиркама. ${ }^{6}$ Мада посредно и расуто, Први косовски бој је предочен у Рјечнику сугерисањем свих битних мотива. Асоцијације се шире и надовезују, од Лазареве женидбе и зидања Раванице, преко Муратовог изазова, окупљања витезова и вечере, до извештаја гласника. Изразита је и сакрална димензија епске стилизације, јер два тумачења алу-

ште*; в. Карановић и Торњански 2004). Звездица означава примере додате 1852, а курзивом је обележена реч протумачена стиховима.

${ }^{3}$ Празнику из старог православног календара додаје историјски контекст: „15ти јунија, када су Србљи изгубили на Косову”, односно: „царство на Косову.” Иста спона је у немачком коментару топонима Косово (поље): „,1389, на Видов дан (15. Јуни).”

${ }^{4}$ На битку из 1448. односи се поређење „Прошао као Јанко на Косову”. Још једна пословица, до данас у употреби, условно би се могла придружити косовској тематици: „Два лоша избише Милоша". Фигуративна конструкција не мора се односити на епски статус Обилића, јер сличну славу заслужује и његов имењак, најмлађи Војиновић. „Распознавање” је јасно у стиху „Узја Милош помамна кулаша”, тим пре што је по предању Обилићев коњ - ждрал. Али, недоумице су изразите при утврђивању сижејног контекста и извора за пример „Шћаше Милош извадити* кавгу".

${ }^{5}$ Корпус песама је очигледан при поређењу друге Пјеснарице и лајпцишког другог тома Народних српских пјесама са првим издањем Рјечника.

${ }^{6}$ Појмови: аздија, алај, бој, Ваистина, вас, вјера, Голубан, Ериег Стјепан/Шћепан, заложити, залагати, застава, затећи се, затомити, згубити, земалски, Злопоглеђа, једек, Југ, кита, ка, књига, коб, коласт, кољено, копрена, Косовка, крсташ, Лаб, Лазарица, маћи, невјера, несретьићи, ограшје, огрезнути, пеар ${ }^{*}$, поводан ${ }^{*}$, подобан, пород, потезати, потоњи, преузети, Раван, разбој, Ситница, сјећи се, слуга, собет, Срђа, старјештво, страшиваи, стремен, суђенииза, таобор, Топлица, убав, (x)yд, удно, часно. Стихове су певали Вуков отац, Тешан, старац Рашко, сељак из Рудничке нахије, трговац из Босне, слепа гусларка из Гргуреваца: Женидба кнеза Лазара, Опет зидање Раванице, Цар Лазар и иарица Милица, Пропаст иарства српскога, Мусић Стефан, Комади бр. 1, 3, 4 и 5, Косовка дјевојка, Обретеније главе кнеза Лазара (Караџић 1988: $\left.32^{\circ}, 36^{\circ}, 45^{\circ}-47^{\circ}, 50^{\circ}-53^{\circ}\right)$. После сусрета са Милијом, уз појмове другог издања Рјечника (Бањска, гариште, главит, пошта, призирати, пријекоран, Сазлија, сјести, уострити, Чечан, шћера) нашли су се стихови из Сестре Леке капетана и Бановић Страхиње (Караџић 1988: $\left.40^{\circ}, 44^{\circ}\right)$ 
дирају на избор између земаљског и небеског царства, и чудо обретења свете кнежеве главе. 7 Фрагменти „ситуација” илуструју тип општих формула или се лако распознају као делови одређене варијанте, односно биографије главних и споредних, типских ликова (Милош и Лазар; Ваистина, Голубан, Југ и Југовићи, Херцег Стјепан, Косанчић и Топлица, Косовка девојка). Тумачења из Рјечника успостављају занимљив „поредак” међу њима. Средишње место заузима Милош, нарочито када се епским стиховима придруже предања. ${ }^{8}$ Лазар чува особине честитог кнеза, обриси портрета Југовића испољавају амбивалентну карактеризацију, а особит статус има Косовка девојка. Али, премда се чин издаје не таји, није споменут Вук Бранковић.

Осим Косова (поља) ${ }^{9}$ међу лексикографским јединицама су топоними, хидроними, ороними и ојконими, непосредно упућени на епски тематски круг. Некада је пратећи коментар тек локализација, а стихове Вук наводи када су споменута места и њему мање позната. Сходно поетици усмене епике и културноисторијских предања, ови појмови су махом повезани са јунаком, независно од историјских упоришта. ${ }^{10}$ За зидање Раванице „крај воде Равана", везано је неколико појмова (бупило*, несретьићи, преузети*, часно*). При тумачењу именице намастир, Вук напомиње како је ту „измолована косовска битка”, а не крије недоумицу при одређењу реке Марице „(у Косову?)”. Неко чудо или зло слути неименована вода, када „провре преосред Косова". ${ }^{11}$

\footnotetext{
${ }^{7}$ Лазарева женидба и предодређеност судбине - књига, суђеница; зидање задужбине - затомити, несретњићи, преузети, собет, часно; Муратов изазов - ка, Лазарица; окупљање војске - станак, Топлициа, узмак; Лазарева дилема - достојати се, земаљски; окупљање ратника и одвраћање од боја - вас, једек, кита, коб, крсташ, слуга, страшивач, чиљети; веридба уочи боја - аздија, копрена; вечера - застава, пеар, старјештво, удно; здравица и сумња у подвижника - вјера, потоњи; Милошев завет - затећи се, тако; издаја и клетва упућена издајнику - кољено, навјера, пород; ухођење војске - подобан, таобор; судар војске - Ериег Стјепан/Шћепан, Злопоглеђа, Лаб, маћи, потезати, Ситнииа, сјећи се, Срђа; Милошев подвиг (сагледан из српске и турске перспективе) - дотући, згубити, подножје; Муратов аманет - дослук; закаснели ратник - забјељети, ограмје, поводан; заручница на разбојишту - заложити, залагати, Косовка, разбој, (x)уд; извештаји са попришта - болан, Ваистина, вас, глас, згубити, злослутан, злосретњи, огрезнути, стремен, чајати; обретење Лазареве главе - убав, скут. Више о мотивима Петровић 2001.

${ }^{8}$ Радња једног предања (затроношити) представља неимарске заслуге Лазаревих кћери.

${ }^{9}$ Међу географским називима који су најзаступљенији у другом издању Рјечника издваја се и Косово (уз: Бачка, Биоград, Бока, Босна, Далмација, Дрина, Дунав, Јадар, Морава, Мачва, Нови, Рисан, Сава, Србија, Сријем, Херцеговина, Хрватска и Црна Гора (Караџић 1986: 1845-1862).

${ }^{10}$ Такве су одреднице: Бањска*, бупило*, Вучитрн, Двориште, затроношити, Звечан (,„рад у Косову близу Митровице, на некаком бријегу, сад пуст”), Косјаница*, Костово* („некакво мјесто у Косову”), Кукуна* и Ружарица*, Куриумлија*, (Кучево* и Браничево*), Мачва, Милочева ирква и намастир ${ }^{*}$, Милочева скакала*, скакалиште*, Приштина*, Сазлија*, чајати, Чечен*.

${ }^{11}$ Део метафоричног сна илуструје еластичност модела и опште формуле. У варијанти песме Млади Марјан и Арнаут Осман, тј. Опет то, али друкчије, преображава се ускочка атмосфера везивањем радње за Косово, Сибињанин Јанка и његовог сестрића (Караџић 1988а: 30, 57).
} 


\section{„Изрази” и „групе речи”}

Ако се Пери-Лордова теорија прислони уз косовски корпус из Рјечни$\kappa a$, очита је постојаност „израза и групе речи” којима се обележавају време, простор, име јунака и радња (Lord 1990: 67, 74). Изразит је моделативни потенцијал иницијалних стихова: - извештај из боја (Ја два врана, два по Богу брата; Богом браћо, два злослутна врана), најава трагичних обрта у форми вилиног кликовања или поласка на поприште (Још зорица не забјељела*/ Ни Даница лица помолила). Уочава се и извесна сижејна неутралност „образаца”, чији би се смисао сачувао при опису било које битке и сваког ратника:

Туд ће поћи војска на алаје; У Турака с' врло добри коњи / И на коњ'ма Турци биюииије; И он води цареве једеке; Ал' (Ситница) мутна и поводна; (Марица) се вода премостила / Од добрије коња и јунака; Па се бише и сјекоше с Турци; Онђе j' пала крвца од јунака / Та доброме коњу до стремена, / До стремена и до узенђије, /А јунаку до свилена паса; Паде крвца коњу до стрмашиа; На њему је коласта аздија, У десној му руци копље бојно, / А у л’јевој алај-барјак златни; Крвава му сабља до балчака; На алату, вас у чисту злату и Вас му коњиц у крв огрезнуо итд.

Бројни примери потврђују изразит визуелни карактер слике, односно природу, стабилност, динамику и доживљај формуле (Радуловић 2015: 9-12).

Вукова тумачења речи указују на низ сложених процеса спевавања рецепције усменог „текста”. Упркос промењеном контексту и неприродној примарној функцији (лексикографска јединица : импровизација песме), песнички исказ води до сижеа варијанте из које се наводи стих / одломак. Само се два пута испољава идеолошка доминанта, битна искључиво за опевање Првог косовског боја:
Небеског се царства достојати* и
Или волиш царству небескоме
Или волиш царству земаљскоме?

Номенклатура такође усмерава пажњу ка тематском кругу (Ваистина, Голубан, Срђа Злопоглеђа, Мурат, Топлица Милан), мада се поједини ликови не везују искључиво за Први косовски бој (Југ и Југовићи, Ериеег Стјепан). Исти принцип ,распознавања” омогућавају и локалитети, било да су део поетике жанра или рефлекси географских реалија. ${ }^{12}$

\footnotetext{
${ }^{12}$ Објашњавајући појмове Кукуна* и Ружарица*, Вук је навео класичну иницијалну формулу (Детелић 1996: 134-137). Изабрана три стиха нису обухватила и имена јунака, а наговештен модел могао се развијати на више начина. Песму Вук није штампао. Ружарица је, очито, типско име цркве (Ружица), прилагођено структури асиметричног десетерца. Ружарицу цркву, али у Срему, спомиње, на пример, певач једне варијанте из Пјеваније (Милутиновић 1990: [15], 81; 467). Међу планинама на простору Косова и Метохије чак се ниједан врх не назива Кукуна (најсличнији би, евентуално, био назив Кукиногледски врв на Шар-планини). Јасно само по себи, као географски појам и симбол, Косово поље не морају епски певачи додатно да локализују. Неуобичајени називи планине и цркве били су путоказ до целовите варијанте. Тумачећи 1852. нове појмове, Вук није променио почетак записа који му је послао поп Вук Мирковић (Караџић 1899: $33^{\circ}$ ). Приређујући Државно издање Вукових рукописа, Љ. Стојановић је приложио и мали круг варијаната овог модела, чију окосницу чини двобој. Три јунака, типично, Вино пију у Косово
} 
Вуково објашњавање појмова потврђује колико је Први косовски бој присутан у памћењу свих његових певача, а реминисценције на важну битку стилизоване су кроз сва епска времена као сведене или развијеније ретроспективе. Поступак се уочава поређењем познатих варијаната са Вуковим тумачењима уз: давори, Косјаница*, Куршумлија*, дослук, дотући. ${ }^{13}$ При епско-мотивској обради бојева ${ }^{14}$ готово се намећу, осим Косова, Лаб и Ситница, док се (типизиран) косовски јунак ,премешта" из једне епске ситуације у другу. ${ }^{15}$

Део примера показује еластичност опште формуле, која се „прилагођава" конкретној - косовској тематици. Теже је открити варијанте, али то не угрожава значење стихова:

Наком* себе спомен оставити (као део Милошевог завета, али и спремности на подвиг сваког јунака);

Пак се носе* по пољу широку (судар две војске, али и део тешког двобоја);

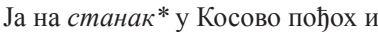

Један другом Божју вјеру дају

На Косову да узмака* нема (као искази Мусића или Милоша и његових побратима, али и одраз емотивне тензије било ког ратника пред битку);

Ја се бојим е ћеш погинути,

Да не чили* јуначко кољено (Миличина молба, али и брига сваке сестре за судбину брата) итд.

Међу песмама Вукових збирки нема стихова из Рјечника који припадају искључиво косовској тематици. Дистих - сцена подразумева суочавање Милоша са султаном, било да је фрагмент дијалога (цара саветује доглавник) или султановог монолога:

Нек целује ногу и папучу

Нек се знаде ђе му је подножје*.

Детаљи су могли бити сегменти „познатих” песама, изостављени при обради текста за штампу. Можда сведоче о неким записима, насталим између 1845. и 1852, а затим изгубљеним. Косовски тематски круг свакако је био шири од Вуковог репрезентативног склопа, што показује и мотив Муратовог аманета. ${ }^{16}$

равно. Показаће се да је најхрабрији - најмлађи и још неафирмисан мегданџија. Пред потурицом Ђурђевића Мејом не скривају страх Марко и Милош, а Облачић Раде осветла образ. У истој песми Ружарица се означава као „Задужбина славног цар-Лазара”. Обрада мотива (Krstić 1984: $338, \mathrm{~S} 6,1 ; 608$, p. v. 66) нема других додирних тачака са тематиком косовских бојева. То је очито и по уводној формули, јер тензија пред битку не одговара таквој сцени испијања вина.

${ }_{13}$ Марко Краљевић укида свадбарину (Караџић 1988: 69, 111); Рајко војвода и Маргита дјевојка (Караџић 1988а: 10, 63-64 и 59-60); Почетак буне против дахија (Караџић 1986а: 24, $365,104)$.

14 Чак и у склопу хроничарског опевања устаничких бојева изразит је удео „старих” мотива (нпр. Бој на Чокешини, Караџић 1986а: 26º), док се наглашава и емотивно-етичка веза нових јунака са подвизима предака: „Помислише на старе јунаке, / Како ваља мријет на мејдану”.

${ }^{15}$ Нпр: потезати* : Јуришић Јанко (Караџић 1988: 52, 53-54); Косанчић Иван као привенаи* : Женидба Ђурђа Смедеревца (Караџић 1988: 79²,108) или Ваистина као име Мусићевог слуге, али и слуге Марка Краљевића (Турци у Марка на слави, 1988: 72 , 40).

${ }^{16}$ Стилизована међу бугарштицама (Богишић $1878: 1^{\circ}$ ), султанова последња жеља добила је посебне димензије при Вишњићевом „објективном” сагледавању разлога подизања Првог срп- 


\section{Различно певање или намјештање речи}

Нарочито када су наведени одломци (заложити, књига, копрена, ограшје, стремен) поређења верзије из Рјечника и збирки показују нијансе у формулацијама. Наоко незнатне разлике могу се тумачити на више начина. Можда је Вук имао више записа „исте” песме, од различитих певача. Светозар Матић без двоумљења тврди да одступања показују Вуково писање по сећању (Матић 1964: 309-320; 1972: 47). Такав слободан однос је и оспораван (Младеновић 1964: 281-292), док има и записа на којима Вук обележава речи како би их придружио лексичком фонду (Караџић 1986: 1532). О таквом читању народне песме при раду на Рјечнику сведочи и Вук сам: „знао сам да ријечи доста имам, али да овако лијепих пјесама (...) имам, то ни сам нијесам знао".

У сваком случају, разликују се примери из Рјечника и збирке:

\begin{tabular}{|c|c|}
\hline СНП II (1845) & $\mathrm{P}\left(1818^{1} ; 1852^{2}\right)$ \\
\hline На јунаку коласта аздија (51: 79) & На њему је коласта аздија $\left(3^{1} ; 33^{2}\right)$ \\
\hline На алату вас у чистом злату $\left(45^{\circ}: 40\right)$ & На алату вас у чисту злату $\left(61^{1} ; 101^{2}\right)$ \\
\hline Маче војску Богдан Јуже стари $\left(46^{\circ}: 47\right)$ & Маче војску стари Југ Богдане $\left(489^{2}\right)$ \\
\hline Невјера ти сједи уз кољено (50\%/II: 48$)$ & Невјера ти уз кољено сједи $\left(576^{2}\right)$ \\
\hline Собет чини српски кнез Лазаре $\left(36^{\circ}: 1\right)$ & Собет чини царе у Крушевцу $\left(779^{1} ; 952^{2}\right)$ \\
\hline Уранила Косовка ђевојка $\left(51^{\circ}: 1\right)$ & Поранила Косовка девојка $\left(415^{2}\right)$ \\
\hline $\begin{array}{l}\text { Је ли много војске у Турака? } \\
\text { Можемо ли с Турци бојак бити? } \\
\text { Можемо ли Турке придобити? (50/II: 3-5) }\end{array}$ & $\begin{array}{l}\text { Има л’ много војске у Турака? } \\
\text { Је л’ подобна да боја убије? }\left(581^{1} ; 732^{2}\right)\end{array}$ \\
\hline $\begin{array}{l}\text { На руци му копрена од злата. } \\
\text { Обазре се и погледа на ме } \\
\text { С руке скиде копрену од злата } \\
\text { С руке скиде, па је мени даде: } \\
\text { На, девојко, копрену од злата, } \\
\text { По чему ћеш мене споменути, } \\
\text { По копрени, по имену моме. (51: 104-110) }\end{array}$ & $\begin{array}{l}\text { На руци му копрена од злата - } \\
\text { / } \\
\text { С руке скиде копрену од злата } \\
\text { С руке скиде, па је мени даде: } \\
\text { На ђевојко копрену од злата, } \\
\text { По чему ћеш мене споменути, } \\
\text { По копрени, по имену моме ( } 327^{1} \text {; } \\
\text { / измењен пример, из баладе о удесу невесте를 }\end{array}$ \\
\hline
\end{tabular}

ског устанка. Из тог сегмента Вишњићеве варијанте наводе се стихови - без измена, уз: дослук и дотући. 


\begin{tabular}{|c|c|}
\hline $\begin{array}{l}\text { Божја помоћ, моја секо драга! } \\
\text { Гди си, душо, на ограшју била? } \\
\text { Откуда ти клобук свиле беле? (...) } \\
\text { Здраво да си, кнежева војводо! } \\
\text { Нисам нигди на ограшју била, } \\
\text { / } \\
\text { Рано ме је пробудила мајка (47: 115-117; } \\
123-125)\end{array}$ & $\begin{array}{l}\text { Божја помоћ Косовко ђевојко! } \\
\text { Ђе си сестро на ограшју била? } \\
\text { Да ђе ли си клобук задобила? - } \\
\text { Д’о Бог добро, кнежева војводо! } \\
\text { Ни’ сам ни(г)ђе на ограмју била, } \\
\text { Нит' сам клобук на боју добила - }\left(487^{1} ; 610^{2}\right)\end{array}$ \\
\hline $\begin{array}{l}\text { Ког јунака у животу нађе } \\
\text { Умива га студеном водицом, } \\
\text { Причешћује вином црвенијем } \\
\text { И залаже љебом бијелијем }\left(51^{\circ}: 14-17\right)\end{array}$ & $\begin{array}{l}\text { Ког јунака у животу нађе } \\
\text { Умије га студеном водицом, } \\
\text { Залије га вином црвенијем } \\
\text { И заложи љебом бијелијем (залагати } 198^{1} \text {, } \\
\text { без примера и } 265^{2} \text {; заложити } 200^{1} \text { и } 267^{2} \\
\text { измењени примери) }\end{array}$ \\
\hline
\end{tabular}

Одступања се могу тумачити и као прилагођавање текста „новој намени”. Пошто су примери истргнути из контекста, редиговање је требало да „обезбеди њихову што већу разумљивост" (Караџић 1986: 1532-1533). Истину је тешко поуздано утврдити, тим пре што граматичке финесе (у чисту/у чистом, стари Југ/Јуже стари) нису пресудне за све промене, нпр. инверзију унутар стиха (уз кољено сједи/сједи уз кољено), употребу заменице уместо именице, прераду полустиха и изостављање стихова (што је графички обележено цртом -).

Највероватније је да Вук примењује оба поступка - преузима реч непосредно из записа, али, када му то успорава иначе тежак посао, он призива стихове из сећања. Ова друга могућност може бити драгоцена за (ре)конструкцију механизма памћења формула. ${ }^{17}$ Разлике показују и процес Вуковог припремања текста за штампу, независно од тога да ли је запис - препис добио од сарадника или је сам бележио (и упамтио) стихове.

Чини се да је на Вука оставио посебне утиске репертоар слепе гусларке из Гргуреваца (Недић 1990: 82-87, Пешић 2017: 49). Измене су готово незнатне. Не угрожавају се: духовно сродство Мусића и Косовке, даривање, слика девојке на попришту. Нису нарушене ни стилске фигуре. Сачувана је и сликовитост песничког исказа. Ипак, није занемарљиво ни оно што је изостављено, ни оно што је додато, нити оно што је потпуно измењено.

Вукове измене показују и како једна, одлично одабрана реч појачава смисао опеване сцене и целе песме. По примеру из Рјечника, Косовкин гест подразумева саосећање брижне девојке. Али, стих из збирке покреће сложе-

17 Уз сопствени репертоар „мужески” песама, Вук 1814. редигује, тада већ чувен, Фортисов запис Хасанагинице (Караџић 1965: 121-123). Одломке је иначе наводио у склопу напомена и предговора збиркама. Мада је сам говорио како није певач, познавање фолклорног фонда, сензибилитет и умешност синтезе омогућили су му уочавање поетике усменог песништва. Један од најпознатијих Вукових аксиома односи се на битне услове спевавања: „Који човек зна педесет различни пјесама, (ако је за тај посао) њему је ласно нову пјесму спјевати” (Караџић 1975: 560). То важно поетичко начело, захваљујући приређивању фолклорне грађе за издања Рјечника, добија и аутобиографски призвук. 
нија значења. Усклађено са девичанском појавом на ратишту, у рано јутро светог дана, причешћивање самртника добија потпуно сакралну димензију. Тај чин, прислоњен затим уз Косовкино сећање, успоставља особен контраст прошлости и будућности - земаљског и вечности. Пред бој јунаци су примили Свету тајну причешћа. На Косово одлазе физички и духовно сједињени са Христом, његовим телом (хлеб) и његовом крвљу (вино). Након окршаја, вино и хлеб приноси Косовка и помаже душама умирућих да напусте сатрвена тела пред узлет до царства небеског.

Можда је то осећала и слепа певачица из Гргуреваца, а Вук је тек нашао реч да савршено употпуни дубину и симболику удеса худе заручнице. Измена је могла бити и другачије мотивисана, тако што је изабран јаснији и једноставнији појам уместо оног из песме. Уз све што је чинио, Вук као да није заборавио ту интервенцију. Јер, за ново издање Рјечника мења примере уз глаголе залагати и заложити. Није се одрекао стихова слепе гусларке, али је 1852. навео само два:

Ког јунака у животу нађе,

Залаже га љебом бијелијем - .

\section{Прекидичи или Комади од различнијех косовскијех пјесама}

Изречено већ 1818, једно Вуково тумачење пружило је повод каснијим научним полемикама, посвећеним постојању, (ре)конструкцији или оспоравању српског епа. Таква форма, нимало случајно, тематски се везује за Први косовски бој:

„Лазарица, f. тако зову слијепци ону велику пјесму од кнеза Лазара и од Косовског боја. Лазарица се почиње:

Цар Мурате у Косово паде,

Како паде ситну књигу пише

Те је шаље ка Крушевцу граду -

А све су остале Косовске пјесме комади од Лазарице.”

Ипак, мада је 1852. ово „толклованије” остало исто, Вук никада није споменуо Лазарииу у збиркама и предговорима. ${ }^{18}$ Непотпуне варијанте објављивао је на више начина, с разним побудама. Некада се због тематике такав текст нашао уз естетски најуспелије песме. Вук их је обележавао поднасловом - „комад(и)”. ${ }^{19}$ Наводио их је и међу напоменама, као потврду да се о истом догађају „различно” пева. ${ }^{20}$

${ }^{18}$ Није то учинио ни када је штампао пет одломака из очевог репертоара. Сваки пут - 1815 , 1823. и 1845. насловом је нагласио да су ти одломци (прекидци - fragmenta) „од различнијех Косовскијех пјесама".

${ }^{19}$ Смрт Душанова, Марко Краљевић у азачкој тамници, Опет то, али друкчије [Секула се у

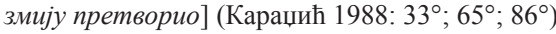

${ }_{20}$ Уз песме: Зидање Скадра, Опет зидање Раванице, Опет то, али друкчије [Секула се у змију претворио], Смрт Јова Деспотовића (Караџић 1988: 26º 97-98; 36 , 157-158, 86 ${ }^{\circ}$ 370; $\left.91^{\circ}, 411\right)$. 
Иначе, фрагментарном трајању епских песама Вук је више пута посветио пажњу, тим пре што је тип (честе) епске стилизације имао више узрока. Истакао је изобиље таквог материјала, од којег би човек могао „накупити читаву књигу” (Караџић 1975: 577). И сам је памтио „комаде” које је чуо у детињству. Узалуд је трагао за „читавом” песмом, јер су сви певачи знали тек исте одломке. Целина „приче” - радње остваривала се тако што се између стихова „приповиједа” (Караџић 1975: 575). Повезивање прозних фрагмената са стиховима могло је бити и последица недовољне даровитости певача „од средње руке”, неповољног контекста импровизације или специфичне тематике локалних подругачица (Караџић 1975: 560-565, 570-574).

И одреднице из Рјечника указале су на сложену природу „комада” од песама - њихово међусобно повезивање или уклапање у приповедања о разним догађајима и јунацима. Такво преношење традиције о Косовском боју илуструју одреднице: бупило*, тама*, чајати. Предање о називу места Царево бупило навео је Вук и уз песму о зидању Раванице (Караџић 1988: 246). Али, другачија је судбина завршетка казивања о тамном вилајету и културноисторијског предања о Обилићу (Двориште). Од песама су остали само трагови - комади наведени у Рјечнику. ${ }^{21}$

Варијанта о војсци некаквог цара, на крају света сред тмине, призвала је из Вукових сећања два стиха, која илуструју сложене амалгаме слике и значења појма - тама*. За смисао предања важна је фигуративна поента, повезана са догађајем, чију драматичност појачава просторна граница између живота и смрти (Самарџија 2009: 5-18). Певање о Косову, међутим, укључује представе о „пошљедњем” времену и есхатолошку визију губитка земаљског царства. Такве „међаше” - општег и локалног поимања „краја” (света), Вук је приближио склопом тумачења. Али, као да се и сам изненадио поређењем које је извео:

„Ваља да се на ову таму и оно мисли гдје се пјева:

Па се носе по Косову равном

Док на таму* починуло сунце."22

Сабласна слика спојила је, заправо, више елемената, различитих и по старини и због жанровских особености. Нестанак сунца угрожава опстанак човечанства у прозним и стихованим легендама, а спасилац (светац) бори се против ђавола или цара Дуклијана. Варијације надметања добра и зла имају исти ток и истог су смисла. Међутим, тама на попришту је карактеристична формула хроничарске епике. Призор-слика добија нове димензије, уз рационализацију архаичне подлоге. Природа таме није космогонијска, већ рефлектује непосредно искуство и/или хиперболизује жестину окршаја - вођеног ватреним оружјем: од онога праха и олова или од онога праха пушчанога и сл. Мада сви певачи и слушаоци знају да се косовски витезови боре сабља-

${ }^{21}$ Истоветне околности прате, на пример, и Вукову напомену уз Змајогњени.

${ }^{22}$ Независно од контекста и структуре десетерца ти стихови нису морали бити сегмент епске стилизације, већ за Косово везана „приповест о борби светла и таме, односно добра и зла” (Петровић: 2001: 273). 
ма, буздованима и копљима, Вук одредницом из Рјечника спаја (нехотице?) две кључне епохе српске историје. Земаљско царство, изгубљено на Косову, враћају устаници, као победници у новим бојевима. ${ }^{23}$

\section{Изгубљене варијанте или Вукова сећања}

Међу епским песмама Вукове збирке извештаје са попришта прима Милица. Мајка Југовића и Косовка девојка су непосредни сведоци исхода боја. Милошева мати се не спомиње, ${ }^{24}$ премда је битан лик предања (и традиције). То потврђују Вукове одреднице из Рјечника. Стихови - сегменти предања подређени су тумачењима локалитета (Двориште, Нечај и Пустопоље - чаја$m u)$. Комад песме подупире истинитост казивања, у недостатку других аргумената. Стихови су можда испевани само са том функцијом. Уверљивост појачава и типска релација између мајке и сина, а породична трагедија поприма значај страдања целог народа.

Другачије је интонирана алузија на исход Косовске битке уз глагол починути*. Осим особитог епитета, ${ }^{25}$ стихове из штампаног и неког (изгубљеног?) текста приближава максимално сажимање богате мотивске мреже на исту ситуацију: ${ }^{26}$

\begin{tabular}{|l|l|}
\hline СНП ІІ (1845) & Р (само у издању 1852) \\
\hline Кад Лазару одсекоше главу & Каде ти је бабо починуо $*$ \\
На убаву на пољу Косову $\left(53^{\circ}: 1-2\right)$ & На убаву на пољу Косову ${ }^{26}$ \\
\hline
\end{tabular}

Контекст ретроспективе се слути као део обраћања младом деспоту Стефану Лазаревићу. Мада из дистиха изостају имена саговорника, Високи Стеван могао би да разговара са калуђером, игуманом, владаром другог царства, чак и са султаном. Ипак, највероватније дијалог воде син и мати му, кнегиња

\footnotetext{
${ }^{23}$ Када је припремао одељак за Живот и обичаје народа српског (Караџић 1916а: 189), Вук је само изоставио стихове Филипа Вишњића (Караџић 1986а: 26º 43-46). Можда ток Вукове асоцијације није био случајан. Опевајући одбрану Чокешине, Вишњић се ослањао на мотиве, карактеристичне за песме о Првом косовском боју (сновиђење, окупљање и причешћивање војске, сукоб у српским редовима, издаја, погибија бранилаца, мотив посечене главе итд. В: Матицки 1982: 69-83).

${ }^{24}$ Тај сегмент Обилићеве поетске биографије илуструју предања уз појам обил (и поновљен исказ уз међер). Коментар о Милошевом коњу прати одредницу ждрал. Као контраст господству Вука Бранковића, у бугарштици је Милоша родила „Влахињица родила под кобилом отхранила” (Петровић 2001: $2^{\circ}$ ). Старац Милија истиче недостојно јунаково порекло, јер га је „кобила родила, / А некака сура бедевија, / Бедевија, што ждријеби ждрале, / Нашли су га јутру у ерђели" (Караџић 1988: 40). Мада је детаљ могуће повезати и са архаичним представама о митским јунацима, Лекина сестра с поругом говори о статусу јунака међу племићима.

${ }^{25}$ Епитет ,убав, заступљен је само у Обретенију главе кнеза Лазара (...) За слепу певачицу из Гргуреваца убаво је не само поље Косово и бео град Скопље, него и мртво Лазарево тело" (Недић 1990: 84). Од шест записа, колико му је Мушицки послао, Вук је навео четири. При реконструкцији репертоара уочени су сродни детаљи у песмама о Марку и захвалном орлу и Дјевојка надмудрила Марка (Латковић 1959: 56-57; Матић 1972: 265-266; Недић 1990: 82-87).

${ }^{26}$ Исти стих наводи Вук и када тумачи придев убав*.
} 
Милица, што сугерише суптилно ублажена истина о удесу кнеза. Скициране околности веома подсећају на сличан фрагмент из комада песме Смрт Душанова. Та секвенца нашла се и међу примерима Рјечника, а по типу „обраде” показује Вукове интервенције у односу на штампани текст из збирке:

\begin{tabular}{|l|l|}
\hline СНП ІІ (1845) & Р (само у издању 1852) \\
\hline $\begin{array}{l}\text { Каде ти је бабо починуо } \\
\text { На самрти царство наручио }\left(33^{\circ}: 79-80\right)\end{array}$ & $\begin{array}{l}\text { На самрти* царство наручио } \\
\text { На самрти кад је починуо. }\end{array}$ \\
\hline
\end{tabular}

Одломак о аманету српског цара Стјепана је испевао старац Рашко. Можда је сличан мотив, везан за друге јунаке, опевала и слепа из Гргуреваца. Није искључено ни да су подударности последица Вуковог састављања неке врсте компилације, спајањем стихова из две варијанте. У сваком случају, аналогије су очите. Почетак и крај причања о вилајету таме приближили су епохе епике (и историје) помоћу одломака познате и изгубљене песме. Тако је изар Лазар - наследник круне Немањића, употпунио њихову славу косовском жртвом. У традицији, Вуковим збиркама и Рјечнику то није једини случај повезивања врхунца и пропасти земаљског српског царства.

\section{Лирско Косово}

Придев убав из песама слепе гусларке придружен је епитетима који се иначе везују за поље (равно, широко) или алтернирају уз одређење Косова. Међу лирским песмама згушњава се целокупна традиција о крвавом разбојишту, такође помоћу епитета:

„Коњ јунака оставио

На злу месту на Косову.”

Лирски јунак обрео се на Косову под необичним околностима. Зло меcто смешта се $y$ Косово, истим прилогом какав Вук користи када тумачи конкретне локалитете. ${ }^{27}$ Цео текст је део најбогатије руковети Вукових „женских” песама (Караџић 1975: 630). Мада су околности типичне за најаву смрти епских јунака, ${ }^{28}$ раздвајање од коња нема трагичан обрт. Коњиц се свети младом бећару због „чести пути у меану”, где време проводи с девојкама, а коња занемарује. С друге стране, смрт од глади и жеђи, која прети коњу еквивалентна је страдању какво се подразумева већ самим спомињањем Косова поља.

Према поетици лирских врста атмосфера свадбе сугерише се на више начина. Једна од учесталих иницијалних формула (Карановић 2019: 105-119) варира древне представе о космичкој оси: Расла јабука Ранку пред двором. ${ }^{29}$

\footnotetext{
${ }^{27}$ Банска*, Звечан, Костово*, Марица, Сазлија*, Чечан*.

${ }^{28}$ Нпр. Радосава Сиверинца, Милоша Кобиловића, Краљевића Марка (Богишић 1878: 49, $1^{\circ}$; Караџић 1988: $74^{\circ}$ ).

${ }_{29}$ Варијанте из табеле припадају усменој лирици (осим две побожне, које су блиске и слепачким клањалицама). Доминирају сватовске песме, а одступања (по теми и лирској врсти) назначена су уз извор:
} 
Са хармоније светова пажња се премешта на лирске јунаке. Под крошњом девојка плете венце, невеста разговара са девером, младожењина мати чека одмену. Дијалог укључује добре жеље намењене младенцима, истиче девојачку лепоту, склад младог пара, отменост жениковог рода, а некад се идеализује живот девојке пре свадбе. Прелазак ка љубавној лирици дочарава чежње и страсти, било да је лепотица недостижна или су љубавници загрљени уснули. Слично се пева и на бабинама, још једном од обреда прелаза. Међу стихованим легендама истом се сликом успоставља граница између раја и пакла, а градација обухвата призоре испаштања грешника. Контаминација паганских и хришћанских слојева изразита је за сведену лирску радњу коледарске песме. Током „припрема” свадбеног весеља млади Краљевић открива мајци да је одабрао духовни пут и заветовао се на службу Богу. Једна легенда гради се

\begin{tabular}{|c|c|}
\hline Уводна формула / иницијални сегмент & Извор \\
\hline (...) А под бором млада Стане & Караџић 1898: $78^{\circ}$ (љубавна) \\
\hline Изникла је наранчица & Караџић 1973: 19, 376 (опис кнеза Л) \\
\hline$[$ И]зрасло ми је дрво зелено & Геземан 1925: $145^{\circ}$ \\
\hline Израсло је танко дрво & Петровић 2001: 41º (опис кнеза Лазара) \\
\hline Под пенџером зелена наранџа & Караџић 1898: $34^{\circ}$ \\
\hline Подрасла је у Нови наранџа & подрасти* \\
\hline Порасла је из раја младика & Караџић 1898: $222^{\circ}$ ( легенда у стиху) \\
\hline Порасла је јелика & Караџић 1898: $261^{\circ}$ \\
\hline Порасле су до три јеле & Караџић 1898: $426^{\circ}$ \\
\hline Порасло је јавор дрво & Петровић 2001: 42 (опис кнеза Лазара) \\
\hline Расла јабука Ранку пред двором & Караџић 1975: $108^{\circ}$ \\
\hline Расла јела насред Сарајева & $\begin{array}{l}\text { Караџић 1975: } 423^{\circ}, 438^{\circ} \text {; Клеут 1983: 96; Матицки } \\
\text { 1985: } 167^{\circ}\end{array}$ \\
\hline Расла јела насред Придвораца & Караџић 1898: $7^{\circ}$ и вар. $2^{\circ}, 26^{\circ}, 465^{\circ}$ \\
\hline Расла кита ракита & Караџић 1973: 101 (митолошка) \\
\hline Расла липа посред поља равна & Караџић 1973: 99 $100^{\circ}$ (побожна) \\
\hline Расла танка јелика & Караџић 1975: $264^{\circ}$ \\
\hline Расло дрво бадемово, танко високо & Караџић 1975: $622^{\circ}$ \\
\hline Расло дрво лаворика & Караџић 1898: 160 (коледарска) \\
\hline Расло дрво сред раја & Караџић 1975: 209 \\
\hline Трепетала трепетљика & Караџић 1898: $273^{\circ}$ (на бабинама) \\
\hline У ливади крушка караманка & Матицки 1985: $92^{\circ}$ \\
\hline
\end{tabular}


по моделу дијалошке словенске антитезе. Метафора, својствена сновиђењима, изједначава Богородицу са целим универзумом, док се фраза „од срца пород” прилагођава благовестима:

„Ђе јој расте покрај срца дрвце,

У ширину по свему свијету,

У висину до ведрога неба" (Караџић 1898: 226º).

Стихови уз Вуково тумачење изведене именице Душанија* не могу се наћи међу његовим збиркама и рукописима. Ипак, пример сведочи о више процеса, битних за Рјечник, традицију и путеве српске књижевности:
„Расла јела на Косову равну
У висину до неба ведрога
У ширину по свој Душанији*,
Под њом седи славни кнез Лазаре.”

Распознавање тока и смисла опеваног догађаја ${ }^{30}$ отежава извесна неусклађеност иницијалне формуле, карактеристичне за лирику, са асоцијацијама покренутим топосом и именом јунака. Да ли је Лазар под јелом сам или са Милицом, седи ли за златним столовима, при некој обредној светковини, уочи крсног имена или пред окупљање војске? Размишља ли усред Косова о задужбини или чека извештај уходе, слуша ли Вукове клевете или већ сумња у Милоша? Није ли честити кнез замишљен над небеским писмом док бира царство којем ће се приволети? Сви су ти наговештаји равноправни, а може им се придодати и низ мотива, чак и мимо јунакове поетске биографије.

Слика из Вуковог тумачења повезује више општих и националних симбола. Поред статуса Косова и кнеза Лазара у српској традицији, шира и архаична подлога је основ иницијалне формуле. И јела сред Косова поља само је једна од варијација представа о средишту света. ${ }^{31}$ Зимзелена крошња сеже до неба, а надвијена над читавим царством спаја пространства и токове времена, материјалне и духовне сфере. За увек зелену јелу, као сеновито, свето дрво и древни храм, везано је велико религијско поштовање (Чајкановић 1985: 123; Софрић 1990: 131). По српској традицији и предању Свети Сава је уморан и стар, уснуо под јелом и ту га је Бог позвао к себи:

„Он се са тог места вазнесе на небо и благослови јелку. Од тада остане јелка благословена, а да се то зна остане зелена и љети и зими” (Ћоровић 1990: 115², 27).

Свето дрво на светом месту (посредно) повезује култ Светог Саве и Светог Кнеза мученика. Та духовна спона светосавља са косовском традицијом најсличнија је тумачењу Богородичиног сна из стиховане легенде:

\footnotetext{
${ }^{30}$ Епски јунак може бити и лик лирске песме. Али, прожимања поетичких система неминовно воде до модификације (уобичајеног) портрета или модела. Певање о Косову и косовским јунацима од друге половине 19. века често се стилизује у лирским минијатурама (Петровић 2001).

${ }^{31}$ B: Bošković-Stulli 1966; Радуловић 2011: 535-550.
} 
„Што ти расте украј срца дрвце, То ћеш родит' Христа бога сина; Што се дрвце широм раширило И покрило с крај' на крај свијета, То ће свијет од греха спасити; Што се дрвце к небу узвисило Са земље ће оцу Богу поћи" (Караџић 1898: 226º).

У небеско царство Бог прима Светога Саву и косовске ратнике. Али, евоцира се и успомена на моћну земаљску царевину. Означавање државе по Душановом имену није уобичајено (Караџић 1966: 87). Певачи и казивачи именују владара другачије - Стефан, Стјепан, Стипан, Шћепан, а царску титулу додељују Немањи и Лазару. Вук је, изгледа, имао другачије склоности, јер је својим насловима песама све крунисане Немањиће изједначио именом првог, Силног српског цара.

Појам Душанија, управо са значењем царевине, не изостаје из лексичког фонда и историје српске књижевности. Јоксим Новић Оточанин, на пример, своје је песме писао „на народну” и објединио под насловом Душанија или знатни догађаји за времена српског изарства, и таки по вему (Будим, Матица српска, 1863). Друго издање Рјечника старије је од Новићеве Душаније, али је занимљив извор којим се Вук послужио.

И именицу и стихове преузео је из текста, штампаног 1844. у Српском народном листу. Сакупљач, Георгије Стефановић, прилог је означио као народну песму. Варијанта, по много чему блиска фолклорном фонду, сродна је и моделу пребацивања цркве буздованом. ${ }^{32}$ Ипак, стилизација се значајно разликује од свих обрада којима наликује. Блиска је епици по јунацима (Лазар; Милош), локализацији и мотивској тенденцији. Одступања и специфични детаљи, међутим, покрећу и сумње у аутентичност записа.

Ратничка иницијација Обилића предочена је кроз прожимања епске афирмације са елементима митолошке лирике и трансформисаним честицама бајке. Колико год да се преплитања облика спонтано одвијају и у усменој комуникацији, овакав спој покренуо је и нову димензију значења опеваних догађаја. Начин карактеризације кнеза Лазара подразумева косовско страдање, а радња песме је из (даљег) пред-времена Косовске битке. Мада епитет славни није необичан, ни за Лазара, ни за друге владаре, разлози Лазареве славе, заправо, још се нису ни стекли. Задовољан земаљским благодетима, овакав Лазар донекле подсећа на кнеза из неких варијаната о зидању Раванице. Али, његова моћ и делокруг најсличнији су анонимном цару из бајки, док младићима поставља - неизвршив задатак.

Сходно формулативном истицању главног протагонисте (и бајке и епских модела) само Милош прихвата постављен изазов. И, пошто испуни погодбу, Обилић мења земаљски статус - постаје Лазарев зет и војсковођа. Од таста прима и „коња виловита”. Уз шестоперац, којим већ чини чуда, добија још један атрибут. Сунце му дарује ханџар „од драгог камења”:

${ }^{32}$ Krstić 1984: 446 (X 17,7), 604. 
„На анџару круна позлаћена,

Позлаћена и бојадисана,

Са јуначком крвцом ишкропана" (Радевић - Матицки 2007: 15²).

Премда је оружје епских јунака често описано и хиперболисано, Обилићев ханџар и начин његовог стицања ближи су поклонима какве заслужује Први, а особит орач (Караџић 1975: 236²). Међутим, Обилићево знамење разликује се по стилизацији и од ових архаичних слојева српске баштине. Као „предзнак Милошевог подвига на Косову” унет је „по форми посве нови мотив: предодређеност јунака Божјом промисли да оствари велики и немогући подвиг" (Радевић - Матицки 2007: 27).

Новине су могле указати на спонтане процесе у животу традиције. Извесније је, ипак, да преображај илуструје последице књижевних интервенција. Ако је неки усмени предложак и постојао, прошао је прераде сакупљача, уредника, ${ }^{33}$ обојице или ,више руку”. ${ }^{34}$ Вук је морао осетити и препознати природу таквог „намештања” речи, али је предност дао занимљивом појму. Душанија се вероватно није могла често чути у народном говору и репертоару певача/казивача. Али, баш таква именица, срочена по „својствима српскога језика", била је захвалан пример за ширење, богаћење и творачке могућности које су се отварале на путевима српске књижевности, не губећи везу са баштином предака.

Концепцијом словара Вук је, можда и нехотице, показао свеопшту повезаност прошлости и будућности. И најмања честица испољила је значај за трајање целокупне културе, премда Косовска тематика сигурно није могла имати иста значења за учене странце и пук који је тек требало описменити. Рјечник је 1818. био „у основи речник говора једног човека” (Караџић 1966: 79). Ново издање је одражавало могућности богаћења лексичког и фразеолошког фонда. Разнородан материјал пропуштен „кроз филтер Вуковог језичког осећања" (Караџић 1986: 1741), повезао је разне сфере баштине. Зато је могуће да се са страница ове књиге „склопе” разнолике тематске целине - од старинских јела и пића, преко демонологије до антропомастике, од симболике биља до етнографије и народне историје. Тумачења садрже и назнаке битне за поетику усмених облика, путеве памћења и „премештања” из усмене комуникације до записаног текста.

Речник и енциклопедија добили су у токовима светске и српске литературе 20. века статус особене наративне форме. Почетком 19. столећа Вук је

${ }^{33}$ Уредник Српских народних новина (1843-1847) био је Теодор Павловић, иначе „најзначајнији српски новинар 30-их и 40-их година 19. века” (Деретић 1979: 214). Георгије Стефановић - Ђорђе Стефановић Којанов (Радевић - Матицки 2007: 16-27) један је од родољубивих свештеника - сакупљача умотворина, који је имао и литерарне амбиције. Поводом његове збирке Вук се осврнуо на „поправљање” записа (Самарџија 2006: 220-227).

34 То није био усамљен случај „приређивања” записа током 19. века (и касније), док стварање дела „на народну” има знатно богатију и дужу историју. 
истим „пословима” пришао на супротан начин, са другачијим циљем. Исписивао је речи и састављао речник као књигу за народ и о свом народу. И, мада се лексичка слика неминовно изменила, Вуков Рјечник је остао особен симбол - средиште светова, раскрсница времена и споменик српске културе.

\section{ЛИТЕРАТУРА}

Богишић1878: В. Богишић, Народне пјесме у старијим највише приморским записима, Београд: СУД; Горњи Милановац, Лио, 2003. ${ }^{2}$

Бошковић-Стули 1966: М. Бошковић-Стули, Дрво насред свијета. Једна народна бајка из Вукове оставштине, посебан отисак, Вуков зборник, Београд: САНУ.

Вукомановић1976: С. Вукомановић, Тумачење речи у Вуковом Српском рјечнику од 1852, Научни састанак слависта у Вукове дане, Београд: Филолошки факултет, 5: 705-717.

Делић 2004: Л. Делић, Косовка девојка: проблем жанровског синкретизма. Научни састанак слависта у Вукове дане, Београд: МСЦ - Филолошки факултет: 63-69.

Деретић 1979: Ј. Деретић, Алманаси Вуковог доба, Београд: Институт за књижевност и уметност - Вук Караџић.

Деретић 1983: Ј. Деретић, Историја српске књижевности, Београд: Нолит.

Детелић 1996: М. Детелић, Урок и невеста. Поетика епске формуле, Београд: Балканолошки институт САНУ.

Карановић 2011: 3. Карановић, Косовка девојка-текст, контекст и жанровске импликације песме, Жива реч. Зборник у част проф. др Наде Милошевић-Ђорђевић, ур. М. Детелић - С. Самарџија, Београд: Балканолошки институт САНУ- Филолошки факултет: 301-315.

Карановић 2019: 3. Карановић, Тамо дољен у џардине ја посејах боб и диње. Уводни стихови и свет флоре у лирским песмама Вукове збирке, Гора Калинова. Биљни свет у традиционалној култури Словена, ур. 3. Карановић, Београд - Vilnius: Удружење фолклориста Србије - Универзитетска библиотека Светозар Марковић - Lietuviu kalbos instituto: 105-119.

Карановић, Торњански 2004: 3. Карановић, С. Торњански, Елементи фантастике у веровањима и предањима Вуковог Рјечника, Mons Aureus, 5-6: 215-223.

Караџић 1898: В. С. Караџић, Српске народне пјесме, V, Државно издање (ДИ), пр. Љ. Стојановић, Београд: Штампарија Краљевине Србије.

Караџић 1899: В. С. Караџић, Српске народне пјесме, VI, ДИ.

Караџић 1965: В. С. Караџић, Мала простонародња славено-сербска пјеснарий (1814). Народна србска пјеснариия (1815), Сабрана дела Вука Караџића (СД), I, пр. В. Недић, Београд: Просвета.

Караџић 1966: В. С. Караџић, Српски рјечник 1818, СД, II, пр. П. Ивић. 
Караџић 1969: В. С. Караџић, Етнографски списи, пр. М. Филиповић - Г. Добрашиновић, Београд: Просвета.

Караџић 1973: В. С. Караџић, Српске народне пјесме из необјављених рукописа В. С. Караиића, I, пр. Ж. Младеновић, В. Недић, Београд: САНУ.

Караџић 1975: В. С. Караџић, Српске народне пјесме I, СД IV, пр. В. Недић.

Караџић 1986: В. С. Караџић, Српски рјечник 1852, СД XI/1-2, пр. Ј. Кашић. Караџић 1986а: В. С. Караџић, Српске народне пјесме IV, СД VII, пр. Љ. Зуковић.

Караџић 1988: В. С. Караџић, Српске народне пјесме II, СД V, пр. Р. Пешић.

Караџић 1988а: В. С. Караџић, Српске народне пјесме III, СД VI, пр. Р. Самарџић.

Клеут 1983. М. Клеут, Лирске народне песме у Летопису Матице српске, Нови Сад - Београд: Матица српска - Институт за књижевност и уметност.

Латковић 1959: В. Латковић, Вуков рачун од јуначких песама, Ковчежић, II: 53-59.

Матић 1964: С. Матић, Огледи о нашој народној поезији, Нови Сад: Матица српска.

Матић 1972: С. Матић, Нови огледи о нашој народној поезији. Нови Сад: Матица српска.

Матицки 1985: М. Матицки, Народне песме у Вили, Нови Сад - Београд: Матица српска - Институт за књижевност и уметност.

Милутиновић1990: С. Милутиновић, Пјеванија црногорска и херцеговачка, пр. Д. Аранитовић, Никшић: Универзитетска ријеч.

Недић 1990: В. Недић, Вукови певачи, Нови Сад: Матица српска.

Пешић 2017: Р. Пешић, О народној књижевности, Београд: Чигоја штампа.

Поповић 1983: М. Поповић, Памтивек: Српски рјечник Вука Ст. Караџића, Београд: Завод за уџбенике.

Петровић 2001: С. Петровић, Косовска битка у усменој поезији, Београд: Гутенбергова галаксија.

Радевић, Матицки 2007: М. Радевић, М. Матицки, Народне песме у српској периодици до 1864, Нови Сад - Београд: Матица српска - Институт за књижевност и уметност.

Радуловић 2011: Н. Радуловић, Дрво света. Проблем поетике једноставних облика на примеру једне формулне слике, Жива реч. Зборник у част проф. др Наде Милошевић-Ђорђевић, ур. М. Детелић - С. Самарџија, Београд: Балканолошки институт САНУ - Филолошки факултет, 535-550.

Радуловић 2015: Н. Радуловић, Слике, формуле, једноставни облици, Београд: Чигоја штампа.

Самарџија 2006: С. Самарџија, Од казивања до збирке народних прича, Бања Лука: Књижевна задруга.

Самарџија 2009: С. Самарџија, Представе о крају света у усменој прози, Синхронијско и дијахронијско изучавање врста у српској књижевности, II, пр. 3. Карановић. Нови Сад: Филозофски факултет, 5-18. 
Стојановић 1987: Љ. Стојановић, Живот и рад Вука Стефановића Караџића, Београд: БИГЗ.

Krstić 1984: B. Krstić, Indeks motiva narodnih pesama balkanskih Slovena, Beograd: SANU.

Lord 1990: A. B. Lord, Pevač priča, I-II, Beograd: Prosveta.

Snežana D. Samardžija

THE FIR GREW ON KOSOVO FIELD

THE BATTLE OF KOSOVO IN VUK'S DICTIONARY

(Summary)

The two editions of Vuk's Serbian Dictionary $(1818 ; 1852)$ contain numerous comments on life, customs, culture, folk literature and history of Serbian people. On this occasion, Vuk's interpretations in which he cited verses and fragments of epic poems about the first battle of Kosovo (the representation of this theme in other forms is also pointed out: proverbs, comparisons, phrases, belief narratives). All these examples are scattered and alphabetically sorted throughout the Dictionary, due to its composition and purpose. However, they still have enough meaning to summon certain poems as well as the entire thematic of Kosovo battle. This kind of Vuk's material depicting the first battle of Kosovo contains: names of heroes, locales and terms from the field of material and spiritual culture; common epic formulae, verses that have been altered/literally cited (regarding Vuk's collections); fragments of poems not found in Vuk's anthologies and manuscripts (they can be found in writings of other recorders). All these examples bear witness about creation, reception and longevity of epic poems. Comparisons between Vuk's tomes and entries in the Dictionary also illustrate his repertoire and his attitude towards folklore text. Of special note is the significancer of Kosovo theme in Serbian national identity. 